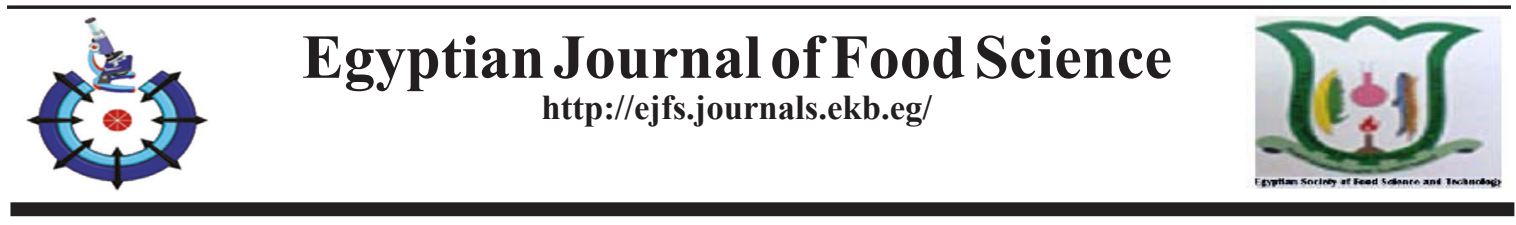

\title{
Controlling of Microbial Hazards for Potato Chips Manufacturing through Food Safety Management System (ISO 22000)
}

\author{
Mahmoud E. Abdelaziz ${ }^{1}$, Mousa A. Salem ${ }^{1}$, Samir Y. Elsanat ${ }^{2}$ and Rasha A. M. \\ Eissa $^{3^{*}}$ \\ ${ }^{1}$ Food Science and Technology Department, Faculty of Agriculture, Tanta University, \\ Egypt \\ ${ }^{2}$ Food Science and Technology Department, Faculty of Agriculture, Kafrelshiekh \\ University, Egypt \\ ${ }^{3}$ Senyorita Company for Food Industries, member of Americana group, Snacks \\ Cluster, Tanta, Egypt
}

$\mathbf{F}$ OOD safety is a fundamental public health concern, and achieving a safe supply poses major challenges for organization involved in the food chain, so numbers of foodborne hazards must be properly analyzed, assessed and managed to meet growing and increasingly complex sets of global food chain. Proper implementation of food hygiene principle across the food chain in conjunction with hazards analysis and critical control points system will ensure food safety. In this study, Microbiological hazards were controlled for two fried potato chips production lines, processing \& packaging for each line starting from raw materials receiving, storage...etc, where microbiolgical tests were carried out at all stages of product production on raw materials received, water used in the manufacturing process, microbiological swabs were taken from the equipment and surfaces of the processing and packaging lines as well as the hands of the workers, in short the stages of potato chips production are as follows: Potatoes receiving $\&$ storage $==>$ Washing $==>$ Peeling $=\Rightarrow$ Manual sorting $==>$ slicing $==>$ washing and remove starch $=>$ Frying $=>$ Optical \& Manual sorting $==>$ Seasoning $==>$ Packaging and print coding $==>$ Palletizing. Based on actual conditions in the plant a specific Hazard analysis and critical control point (HACCP) model has been developed to ensure safe product, reduce and support the traditional inspection and quality procedure of fried potato chips product through food safety management system ( FSMS-ISO 22000), the prerequisite programs (PRPs), operational prerequisite programs (OPRPs), critical control point (CCP), critical limits, preventive, monitoring procedures and corrective actions have been designed in this HACCP plan.

Keyword: Food safety management system, ISO 22000, HACCP, Hazard,Critical control point, Critical limit, Prerequisite programs, Operation prerequisite programs.

\section{Introduction}

Fried potato chips (FPCs) are the most commonly consumed snack, especially by children. Potato chips are the most widely accepted snack food. They are not seasonal and consumed by one and all right round the year. The market for potato chips is an assured and growing one. Potato chips processing technology is relatively new field of study, research and business strategy in Egypt.
Currently several business groups are starting to develop the product and expanding their business in this field (Bardic, 2001 and Easdani et al., 2012). Potatoes are the main raw material for the potato chips industry, which is the key to the quality of the consumer. The potato is a starchy, tuberous crop from the perennial nightshade Solanum tuberosum. Potato has become a staple food in many parts of the world and an integral part of much of the world's food supply (Abd-

"Corresponding author: eissarasha@yahoo.com

Received:11/3/2020; accepted:16/4/2020

DOI: 10.21608/EJFS.2020.23183.1044

C2020 National Information and Documentation Centre (NIDOC) 
Elgawad and Youssef, 2008). Potatoes are first selected and diseased and green ones segregated. The potatoes to be processed are washed and peeled in their respective machines. They are then sliced with the thickness ranging from 1 to 1.5 millimeters. Immediately after slicing, they are blanched in a bucket of bisulphite solution for a few seconds. The excess water is removed by spinning the slices in a centrifugal machine. The slices are then fried in medium hot oil at 180 degrees centigrade for 2 minutes to obtain crisp golden-brown chips. The chips are transferred to the spice coating pan where salt and spices are dusted. They are then packed in pouches (Geiger, 2011). The importance of HACCP that is it asystematic approach for identification and assessment of hazards associated with manufacturing, distribution, and use of food products as well as the definition of preventative measures for their control so it saves the business money in the long run, discovering root causes for problems to prevent recurrence of problems again, reducing and support the traditional inspection and quality procedures, it focuse solely on significant hazards that are reasonably likely to result in unacceptable health risk to consumers. Finally, it is a tool and is not designed to be a standalone program to be effective, other tools must include adherence to PRP like good manufacturing practices, sanitation standrds procedures, and a personal hygiene program, etc. (ISO 22000, 2018). Food safety is the utilization of resources and strategies to ensure that foods are properly produced, processed, and distributed so they are safe for consumption. (Codex, 2009; Noble et al., 2009 and ISO 22000, 2018). ISO 22000 is an ideal package for food manufacturers looking to meet international food safety standards. This system meets the requirements of international standard for FSMS.

The objective of this study is to ensure that all products manufactured by the company are safe and fit for consumption acoording to our end customer expects, so in this study HACCP plan was designed for potato chips production through FSMS - ISO 22000 based on actual conditions in the plant to produce safe product, Accordingly this study is specifically designed to develop HACCP plan based on the HACCP principles that can be applied in a potato processing plant toProvide information regarding the system's maintenance requirements and finished product quality impact.

Egypt. J. Food. 48, No.1 (2020)

\section{Materials and Methods}

Materials

The present study was carried out at processing and packaging Herms potato chips provided from a plant at Central Delta, Egypt, during the spring season of the year 2018. All chemicals, solvents, media in this study, were purchased from ElGomhorea Company for chemicals and drugs, Tanta, Egypt.

Devices used

- Water bath $(\mathrm{CBM})$ - Italy $\left(0-120^{\circ} \mathrm{C}\right)$.

- Oven (Titanox) - Italy $\left(0-210^{\circ} \mathrm{C}\right)$.

- Autoclave (Tomy Es -315) - England (0 $132^{\circ} \mathrm{C}$ ).

- Hot plate with stirrer (UC 152) - Germany (0 $-400^{\circ} \mathrm{C}$ ).

- Incubator - Memmert (IN110) - Germany (0 $-40^{\circ} \mathrm{C}$ ).

- Incubator VELP (FOC 225E) - Italy $\left(3-50^{\circ} \mathrm{C}\right)$.

- Balance (Bp610) Sartorius - Germany (0$550 \mathrm{~g})$.

Media used

- maximum recovery diluent (MRD) - OXOID - United kingdom.

- Plate count agar (PCA) - OXOID - United kingdom.

- Dichioran 18\%glycerol agar (DG18) OXOID - United kingdom.

- Violet red bile lactose agar (V R B L) - Mark - Germany.

- Violet red bile glucose agar (V R B G) - Mark - Germany.

- Manitol egg yolk polymyxin agar (MYP) Himedia - India.

- Baird parker agar (BP agar) - Himedia - India

- Tryptone-bile-glucuronide agar (TBX) - LAB M - United kingdom.

- Buffered Peptone water solution - LAB M United kingdom.

- Tetra Thionate Broth (TTB) ) - LAB M - United kingdom.

- Rababort Vassiliadis media(RVS) - LAB M United kingdom.

- Xylose lysine Deoxycholate agar (XLD), Heakton Entric Agar(HEA) - Himedia - India.

- Egg yolk tellurit, Egg yolk tellurite emulsion, polymix B supplement - Himedia - India.

Specification

Microbiological tests for the potato chips manufactured were estimated according to each microbe, according to the following international standards. 


\section{Methods}

Microbiological analysis

Preparation of samples:

Samples were prepared according to (ISO/6887-1/1999). as follows: Samples were taken using sterilized tools. $10 \mathrm{~g}$ sample were added to $90 \mathrm{ml}$ maximum recovery diluent $\left(10^{-1}\right.$ dilution), $1 \mathrm{ml}$ from previous solution was taken to $9 \mathrm{ml}$ maximum recovery $\left(10^{-2}\right.$ dilution $)$ and so on to make serial dilution.

\section{Total plate count (TPC)}

It was determined on plate count agar media as recommended by (ISO 4833/2013). The plates of different dilutions were incubated at $(30 \pm 1)$ ${ }^{\circ} \mathrm{C}$, for $(72 \pm 3 \mathrm{hr})$.

\section{Mold and yeast counts (DG18)}

It was determined on Dichioran $18 \%$ glycerol agar media as recommended by (ISO 21527$2 / 2009$ ). The plates of different dilutions were incubated at $(25 \pm 1){ }^{\circ} \mathrm{C}$, for 5-7 days.

Coliform group count ( $V R B L)$

Total coliform count was detected on Violet red bile lactose agar media according to (ISO 4832:2006). $1 \mathrm{ml}$ of sample (dilutions) for count or any quantity of dilutions for detection, media added by pour plate method, second layer of media was added after solidity, the plates were then incubated at $37 \pm 1^{\circ} \mathrm{C}$ for $24 \mathrm{hr}$.

\section{Bacillus cereus (MYP agar)}

Bacillus cereus count was detected on Manitol egg yolk polymyxin agar media according to (ISO 7932:2004). $1 \mathrm{ml}$ of sample (dilutions) for count or any quantity of dilutions for detection on surface of the media (surface plat method), then incubated at $30 \pm 1^{\circ} \mathrm{C}$ for $72 \mathrm{hr}$.

Staphylococcus aureus (B P)

Staphylococcus aureus was detected on Baird parker agar media according to (ISO 6888-1/ 2003). $1 \mathrm{ml}$ of sample (dilutions) for count or any quantity of dilutions for detection on surface of the media (surface plat method), then plates were then incubated at $37 \pm 1^{\circ} \mathrm{C}$ for $48 \mathrm{hr}$.

\section{Enterobacteriaceae ( $V R B G)$}

Enterobacteriaceae was detected on Violet red bile glucose agar media according to (ISO 215282004). $1 \mathrm{ml}$ of sample (dilutions) for count or any quantity of dilutions for detection, media added by pour plate method, second layer of media was added after solidity, then plates were incubated at $37 \pm 1^{\circ} \mathrm{C}$ for $24 \mathrm{hr}$.

\section{E. coli $(T B G A / T B X)$}

E. coli of samples was detected on Tryptonebile-glucuronide agar media according to (ISO 16649-2/ 2001). $1 \mathrm{ml}$ of sample (dilutions) for count or any quantity of dilutions for detection, media added by pour plate method then the plates were incubated at $44 \pm 1^{\circ} \mathrm{C}$ for $24 \mathrm{hr}$.

Salmonella: (BP, TTB, RVS, XLD, HEA)

Salmonella was detected according to (ISO $6579 / 2002$ ). $25 \mathrm{~g}$ of sample were added to $225 \mathrm{ml}$ Buffered Peptone water solution, incubated at 37 $\pm 1^{\circ} \mathrm{C}$ for $24 \mathrm{hr}, 1 \mathrm{ml}$ of previous added to Tetra Thionate Broth media and $0.1 \mathrm{ml}$ to Rababort Vassiliadis media, incubated at $37^{\circ} \mathrm{C}, 41.5{ }^{\circ} \mathrm{C}$ respectively, after that each of previous broth media was added to Xylose lysine Deoxycholate agar, Heakton Entric Agar respectively by sterlised loop and incubated for $37 \pm 1^{\circ} \mathrm{C}$ for $24 \mathrm{hr}$.

\section{Air sampling}

Mas 100 device designed to draw air samples from high hygiene zone where the dish containing on solid media is placed inside device and turning on the device to pull $1000 \mathrm{~L}$ of air for $10 \mathrm{~min}$ on the dish then incubating dishes containing the solid media at suitable temperature for each microbe.

\section{Prerequisite programs (PRPs) \\ Factory layout}

Barriers had to be designed and established between hygiene zones based on the zoning plan (high, medium and low hygiene zone) to protect products from cross contamination. Barriers types (walls, doors, air curtains and change shoes) as shown in Fig. 1.

\section{In coming packaging materials}

Packaging film, coupons inserted for promotions were examined. Samples were withdrawn to conduct microbiological tests to ensure their safety based on specific criteria.

\section{Cleaning and sanitation requirements}

Cleaning was supervised well, operating methods employed, verification actions, persons responsible and records also maintained to verify appropriate cleaning has taken place in each area. 

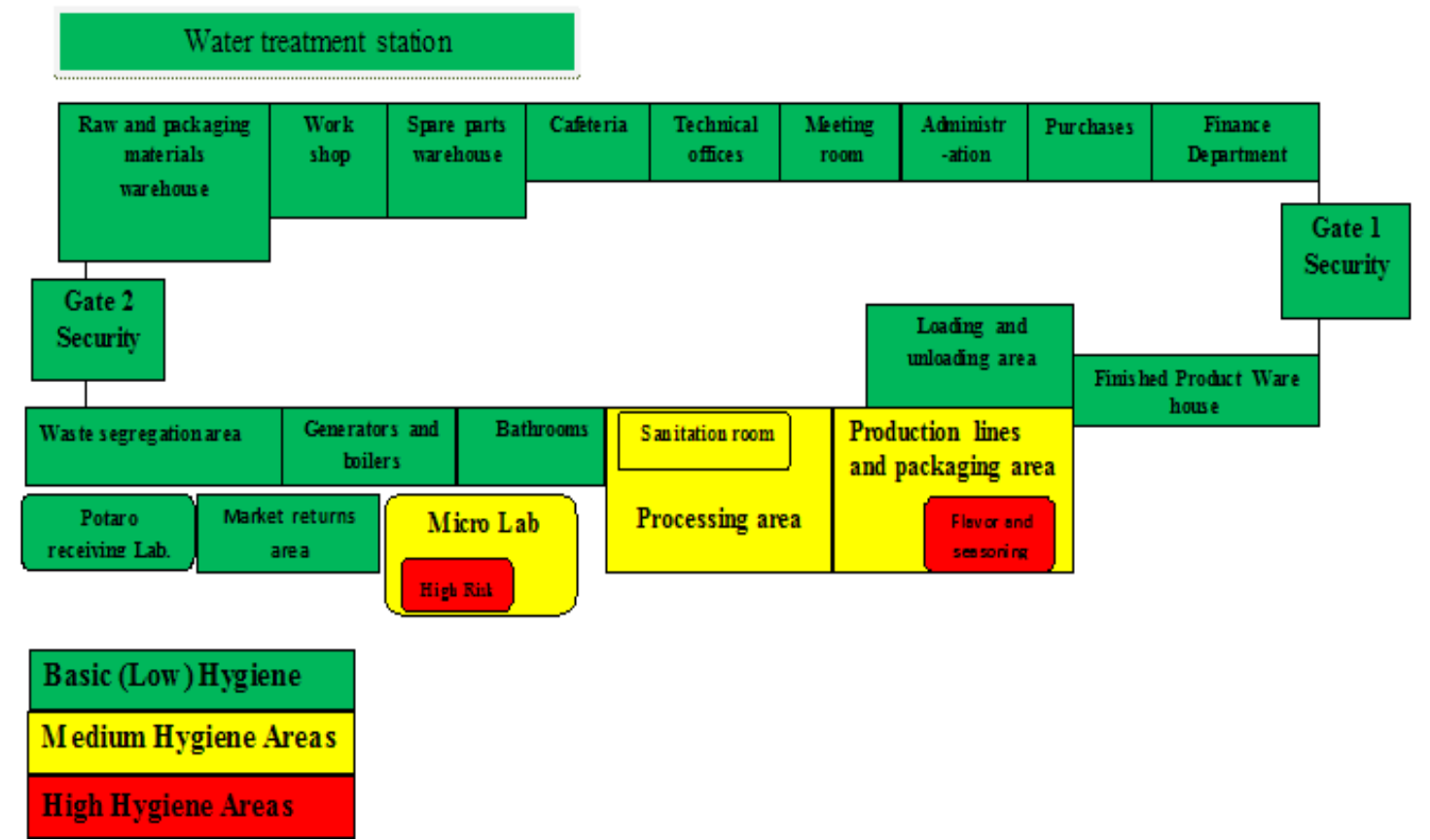

Fig. 1. Factory layout.

\section{Housekeeping}

Cleaning and housekeeping plan has been done covering all the factory layout. $5 \mathrm{~S}$ is a 5-steps visual and simple method for maintaining the workplace, wich highly recommended to ensure, support good housekeeping and therefore improve the work environment, operation, maintenance and safety. Sort $==>$ Set in order $==>$ Shine $==>$ Standardize $==>$ Sustain (Hirano, 1995). Frequency of cleaning and monitoring as per factory housekeeping plan (Table 1).

\section{Water quality}

Water analysis included microbiological and physical test to meet all the egyptian local regulatory requirements, Egyptian standard for drinking water. (E. S 190-1 / 2007).

\section{Personal hygiene policy}

Personal swabs were taken before and after cleaning and disinfection person's hands to ensure effectiveness of person hygiene policy for staff.

\section{Training program requirements}

Atraining business plan was incorporated into the annual operating plan and training programs included, appropriate trainers, verification activities to assess training effectiveness.

\section{Result and Discussion}

Prerequisite programs (PRPs)

Prerequisite program (PRP) is implemented in accordance with codex general principle of food hygiene and good manufacturing practice to establish basic conditions that are suitable for the production and handling of safe food at all stages of the food chain (SCV, 2006).

\section{Factory Layout}

Seasoning in Packaging area was considered high hygiene zone where microbiological analysis were conducted by air sampling withdrawed from different locations of area. The obtained results are shown in Table 2, results revealed that the air after implementing hygienic requirements of seasoning area (filtrated air, implemement personal hygiene policy, dry clean and desinfiction spray were used) was free from any pathogenic bacteria and had low microbial load of bacteria and mold \& yeast counts, but the air of the same area before implementing hygienic requirements has high loads of bacteria, mold and yeast counts. In case of deviation, corrective action must be taken by checking air filter, maintaining or changing filter if necessary, training persons and the retesting again is required. Our results were in agreement with (Khateb, 2014). 
TABLE 1. Factory cleaning and housekeeping plan.

\begin{tabular}{|c|c|c|c|c|c|c|c|}
\hline 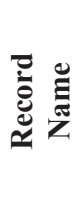 & 莺 & 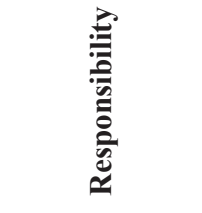 & 总 & 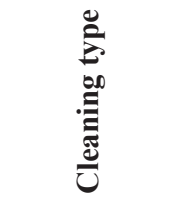 & 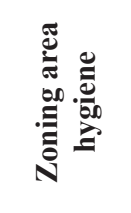 & 咅 & 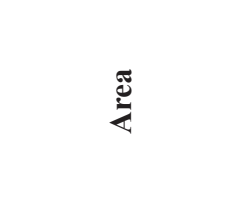 \\
\hline $\mathrm{X}$ & Security Team & & & & & & Security Gate 1 \\
\hline$X$ & $\begin{array}{c}\text { Administration } \\
\text { Affairs }\end{array}$ & & Daily & & & & $\begin{array}{l}\text { Factory } \\
\text { premises area }\end{array}$ \\
\hline$X$ & Finance team & & & & & & $\begin{array}{l}\text { Finance } \\
\text { building }\end{array}$ \\
\hline $\mathrm{X}$ & HR \& Admin & Housekeepers & Twice/week & dry, wet & & & $\begin{array}{l}\text { Administration } \\
\text { offices }\end{array}$ \\
\hline $\mathrm{X}$ & HR & & & & & & Meeting Room \\
\hline $\mathrm{X}$ & $\begin{array}{l}\text { Technical } \\
\text { Managers }\end{array}$ & & & & $\begin{array}{c}\text { Low } \\
\text { hygiene }\end{array}$ & Outdoor & $\begin{array}{l}\text { Technical } \\
\text { Offices }\end{array}$ \\
\hline$X$ & WH Keeper & WH workers & & dry & & & $\begin{array}{l}\text { Spare parts } \\
\text { WH }\end{array}$ \\
\hline $\mathrm{X}$ & & & & & & & FP Warehouse \\
\hline$X$ & canteen staff & canteen staff & & dry, wet & & & Cafeteria \\
\hline$X$ & $\begin{array}{l}\text { Administration } \\
\text { Affairs }\end{array}$ & $\begin{array}{c}\text { Factory } \\
\text { Housekeepers }\end{array}$ & Daily & wet & & & $\begin{array}{l}\text { Bathrooms and } \\
\text { Toilets }\end{array}$ \\
\hline $\begin{array}{l}X \\
X\end{array}$ & $\begin{array}{l}\text { Maintenance } \\
\text { Supervisor }\end{array}$ & $\begin{array}{l}\text { Maintenance } \\
\text { Technician }\end{array}$ & & $\begin{array}{l}\text { dry, grease- } \\
\text { oil removal }\end{array}$ & & & $\begin{array}{l}\text { Generators } \\
\text { Area } \\
\text { Boiler Room }\end{array}$ \\
\hline$X$ & QA & Production & & dry, wet & Middum & & $\begin{array}{l}\text { Sanitation } \\
\text { Room }\end{array}$ \\
\hline$X$ & Production & Workers & & & & Indoor & Processing Area \\
\hline $\mathrm{X}$ & Engineer & & Twice/week & & & & Packaging Area \\
\hline $\mathrm{X}$ & WH Keeper & WH workers & Daily & & Low & Outdoor & RM Warehouse \\
\hline$X$ & $\begin{array}{c}\text { General } \\
\text { Maintenance } \\
\text { Officer }\end{array}$ & $\begin{array}{l}\text { Maintenance } \\
\text { Technician }\end{array}$ & Weekly & dry & hygiene & & Work Shop \\
\hline $\mathrm{X}$ & $\begin{array}{l}\text { Production } \\
\text { Engineer }\end{array}$ & $\begin{array}{c}\text { Production } \\
\text { Operators }\end{array}$ & & $\begin{array}{l}\text { dry \& spry } \\
\text { disinfection }\end{array}$ & $\begin{array}{c}\text { High } \\
\text { hygiene }\end{array}$ & Indoor & $\begin{array}{l}\text { Flavor adding } \\
\text { \& Seasoning }\end{array}$ \\
\hline \multirow{3}{*}{$X$} & \multirow{3}{*}{ Lab Team } & \multirow{3}{*}{$\begin{array}{l}\text { Quality } \\
\text { Technician }\end{array}$} & \multirow[t]{3}{*}{ Daily } & dry, wet & $\begin{array}{l}\text { Middum } \\
\text { hygiene }\end{array}$ & \multirow{3}{*}{ Outdoor } & $\begin{array}{l}\text { Chemical } \\
\text { Laboratory } \\
\text { Microbiological } \\
\text { Lab (Media } \\
\text { Preparation) }\end{array}$ \\
\hline & & & & $\begin{array}{c}\text { dry, wet } \\
\text { controlled, } \\
\text { spry } \\
\text { disinfection }\end{array}$ & $\begin{array}{c}\text { High } \\
\text { hygiene }\end{array}$ & & $\begin{array}{l}\text { Microbiological } \\
\text { Lab } \\
\text { (High Risk } \\
\text { Area) }\end{array}$ \\
\hline & & & & dry, wet & $\begin{array}{c}\text { Low } \\
\text { hygiene }\end{array}$ & & $\begin{array}{l}\text { Potatoes } \\
\text { Receiving Lab }\end{array}$ \\
\hline
\end{tabular}

FP: Finished product. WH: Warehouse. Indoor: In production area. Outdoor: Out production area. 
Incoming packaging materials

Table 3 shows that film used in packaging and coupon for promotion samples taken during receiving were within the acceptable microbiological limits and free of pathogens microorganisms. In case of nonconformity, they are returned to the supplier company.

Cleaning and sanitation programs requirements $(C \& S p)$

Acomprehensive and documented cleaning plan was established, this plan included specific instructions for the cleaning of each piece of equipment, installation, process area, warehouse, etc. to ensure effectiveness of ( $\mathrm{C} \& \mathrm{Sp})$. The microbiological tests of the swabs were taken from different equipment from the processing and packaging lines before and after the implementation of the cleaning and sanitation programs (C \& S). in Table (4), the results shows that total plate count decreased significantly and pathogens microorganisms (Staphylococcus aureus, Bacillus cereus, Enterobacteriaceae) were not detected after implementing $(\mathrm{C} \& \mathrm{~S})$ programs, but before cleaning and disinfection the results were outside the permissible limits. In case of deviation corrective action should be taken by recleaning, resanitizing again, retraining, awareness of employees and reswabbing and retest again to ensure results within the acceptable limits.

Our results in agreement with (Forsythe and Hayes, 1998 and Khatab Heba, 2014) who reported that standard number of good microbial load of spoilage microorganisms of food contact surfaces ranged between $2-10 / \mathrm{cm} 2$ while the safe microbial load number is less than $1 / \mathrm{cm}^{2}$

TABLE 2. Microbiological analysis of high hygiene zone before and after implement hygienic requirements (air sampling).

\begin{tabular}{|c|c|c|c|c|c|c|}
\hline \multicolumn{5}{|c|}{ Microbial count (cfu/plate) } & \multirow[b]{2}{*}{ Test time } & \multirow{2}{*}{$\begin{array}{c}\text { Seasoning } \\
\text { area }\end{array}$} \\
\hline $\begin{array}{c}\text { Bacillus } \\
\text { cereus }\end{array}$ & E. coli & $\begin{array}{c}\text { Staphylococcus } \\
\text { aureus }\end{array}$ & $\begin{array}{c}\text { Mold \& } \\
\text { yeast }\end{array}$ & $\begin{array}{l}\text { Total plate } \\
\text { count }\end{array}$ & & \\
\hline Nil & Nil & Nil & $<30$ & $<50$ & ---- & Limit \\
\hline Nil & Nil & Nil & $100^{\mathrm{a}}$ & $200^{\mathrm{a}}$ & Before & \multirow{2}{*}{ Front } \\
\hline Nil & Nil & Nil & $20^{\mathrm{d}}$ & $33^{\mathrm{de}}$ & After & \\
\hline Nil & Nil & Nil & $70^{\mathrm{b}}$ & $150^{\mathrm{b}}$ & Before & \multirow{2}{*}{ Middle } \\
\hline Nil & Nil & Nil & $20^{\mathrm{d}}$ & $20^{\mathrm{e}}$ & After & \\
\hline Nil & Nil & Nil & $45^{\mathrm{c}}$ & $75^{\mathrm{c}}$ & Before & \multirow{2}{*}{ End } \\
\hline Nil & Nil & Nil & $15^{\mathrm{d}}$ & $15^{\mathrm{e}}$ & After & \\
\hline
\end{tabular}

${ }^{*} \mathrm{cfu} /$ plate = colony forming unit $/$ plate.

*The limits are according to internal specifications.

* Values followed by different letter in column are significantly different at $p<0.05$.

TABLE 3. Microbiological swabs of received film rolls and coupon promotions.

\begin{tabular}{ccll}
\hline Film rolls & Coupon & Limits & Microbiological tests (cfu/swab)* \\
\hline Nil & 20 & $\leq 1000$ & Total plate count \\
Nil & Nil & Nil & Mold \& yeast \\
Nil & Nil & Nil & Staphylococcus aureus \\
Nil & Nil & Nil & Bacillus cereus \\
Nil & Nil & Nil & Enterobacteriaceae \\
\hline
\end{tabular}

${ }^{*} \mathrm{cfu} / \mathrm{swab}=$ colony forming unit $/ \mathrm{swab} .{ }^{*} 1000 \mathrm{cfu} / \mathrm{swab}=1 \mathrm{cfu} / 100 \mathrm{Cm}^{2}$.

*Limits are according to American public health association.

Egypt. J. Food. 48, No.1 (2020) 


\section{Water quality}

The water potability was tested to comply with the national water quality standard of Egypt. The water used for manufacturing and drinking was free from the pathogen and total plate count at 22 and $37^{\circ} \mathrm{C}$ within limits as shown in Table 5 . Correction and preventive action shall be taken in case of deviation results of analysis out of limits, by changing filters or maintenance of filters, water reservoirs. Our results were in agreement with, (Easdani et al., 2012). Methos according to (ISO 9308-1/2000).

\section{Personal hygiene}

Table 6 shows that the microbiological tests results of swabs taken before and after implementing $\mathrm{t}$ personal hygiene from two processing lines (manual sorting) and two packaging lines (seasoning) to ensure the effectiveness, cleaning and disinfection program for workers. The results indicate that high load of Total plate count and pathogenic microbes (Staphylococcus aureus, Enterobacteriaceae) were detected before cleaning \& disinfecting of workers hands. But after implementing effective hand washing program we found all results of swabs taken within the acceptable limit for all workers. corrective action must be taken in case of deviation by retraining persons and reswabbing again.

\section{Training program requirements}

Each functional department had identified training needs and training for all employees including fixed, temporary and contractors where appropriate to ensure that they have the appropriate level of education, experience and training necessary to effectively perform the required activities specified in the company food safety policy (ISO/TS 22002-1, 2009). Annual food safety training plan has beeb established, which identified training items as shown in Table 7.

\section{HACCP plan}

Implementing the food safety management system (FSMS) by the CODEX-12 step logic sequence for the application of HACCP as follows:

Assembling the HACCP team

Administrative letter, issued from top management, mentioning responsibilities and authorities of the food safety team and food safety team leader as an evidence of the top management commitment towards food safety.

\section{Product description and intended use}

All key physical, chemical, microbiological characteristics of the products manufactured on the process line according to (E.S: 1629, 2017).

construct flow diagram, and process step

All processes steps and activities were described in details to explain the purpose of each step in the process.

Hazard analysis (List hazards, conduct hazard analysis, consider control measures)

Information about hazards has been Collected and evaluated, hazards analysis and assessment were done for each step of potato chips manufacturing starting from receiving till finished product storage. as shown in Tables $8-10$.

\section{Determining CCPs and it is critical limits}

Decision tree to determining CCPs for each identified significant hazard (CAC/RCP-4, 2003). To determine the critical limits for each CCP by using supporting documented specifications as well as OPRP if necessary. To differentiate between the control measure classifications either CCP or OPRP for each identified significant hazard using (FSSC 22000, 2019).

Monitoring, verification of CCP - OPRP, corrective action, documentation and record keeping

All CCPs, OPRP points identified wrere monitored and verified (Easdani et al. 2012). hazards description, critical limit, observationmonitoring procedure, responsible person and corrective action in HACCP plan included one point OPRP for fried potato chips plant, which represent a microbiological hazard, which was (frying potato). As shown in Table 11. Records of monitoring were kept to ensure the effectiveness of the HACCP system.

From Table 10 frying step is OPRPs (microbiological hazard) which was assessed according to hazards matrix =likelihood of accurance (1)*severity of health effect (A), where (1) mean unlikely occureand (A) mean can cause fatality, so it was considered a significant hazard as shown in Fig. 2.

All OPRP points identified was monitored and verified as shown in Table 11.

Egypt. J. Food. 48, No.1 (2020) 
TABLE 4. Microbiological analysis of swabs taken from Equipment of two processing and packaging lines before and after implementation of $\mathrm{C} \& \mathrm{~S}$ programs.

\begin{tabular}{|c|c|c|c|c|}
\hline After $\mathbf{C} \& \mathbf{S}$ & Before $\mathbf{C} \& \mathrm{~S}$ & Line & Tests \& limits & Location \\
\hline $4.7 \times 10^{2 b}$ & $2.2 \times 10^{5 \mathrm{a}}$ & 1 & \multirow{2}{*}{ Total plate count $(1000 \mathrm{cfu} / \mathrm{swab}) *$} & \multirow{10}{*}{ Bucket ${ }^{(A)}$} \\
\hline $4.3 \times 10^{2 \mathbf{b}}$ & $9.1 \times 10^{3 \mathrm{a}}$ & 2 & & \\
\hline Nil & $2.1 \times 10^{3 \mathrm{a}}$ & 1 & \multirow{2}{*}{ Mold \& yeast (Nil/swab) } & \\
\hline Nil & $4 \times 10^{2}$ & 2 & & \\
\hline Nil & Detected & 1 & \multirow{2}{*}{ Staphylococcus aureus (Nil/swab) } & \\
\hline Nil & Nil & 2 & & \\
\hline Nil & Detected & 1 & \multirow{2}{*}{ Bacillus cereus (Nil/swab) } & \\
\hline Nil & Nil & 2 & & \\
\hline Nil & Detected & 1 & \multirow{2}{*}{ Enterobacteriaceae (Nil/swab) } & \\
\hline Nil & Nil & 2 & & \\
\hline $3.5 \times 10^{2 \mathrm{~b}}$ & $6.6 \times 10^{5 a}$ & 1 & \multirow{2}{*}{ Total plate count (1000cfu/swab) } & \multirow{10}{*}{ Drums $^{(B)}$} \\
\hline $3.8 \times 10^{2 \mathbf{b}}$ & $7.8 \times 10^{3 \mathrm{a}}$ & 2 & & \\
\hline Nil & $1.9 \times 10^{4 a}$ & 1 & \multirow{2}{*}{ Mold \& yeast (Nil/swab) } & \\
\hline Nil & $2.1 \times 10^{3 a}$ & 2 & & \\
\hline Nil & Detected & 1 & \multirow{2}{*}{ Staphylococcus aureus (Nil/swab) } & \\
\hline Nil & Detected & 2 & & \\
\hline Nil & Detected & 1 & \multirow{2}{*}{ Bacillus cereus (Nil/swab) } & \\
\hline Nil & Detected & 2 & & \\
\hline Nil & Nil & 1 & \multirow{2}{*}{ Enterobacteriaceae (Nil/swab) } & \\
\hline Nil & Detected & 2 & & \\
\hline $2.9 \times 10^{2 \mathrm{~b}}$ & $1.2 \times 10^{4 a}$ & 1 & \multirow{2}{*}{ Total plate count (1000cfu/swab) } & \multirow{10}{*}{ Vibrators $^{(\mathrm{C})}$} \\
\hline $5.3 \times 10^{2 \mathbf{b}}$ & $3.1 \times 10^{4 a}$ & 2 & & \\
\hline Nil & $8.1 \times 10^{2 \mathrm{a}}$ & 1 & \multirow{2}{*}{ Mold \& yeast (Nil/swab) } & \\
\hline Nil & $3.6 \times 10^{3}$ & 2 & & \\
\hline Nil & Detected & 1 & \multirow{2}{*}{ Staphylococcus aureus (Nil/swab) } & \\
\hline Nil & Nil & 2 & & \\
\hline Nil & Detected & 1 & \multirow{2}{*}{ Bacillus cereus (Nil/swab) } & \\
\hline Nil & Detected & 2 & & \\
\hline Nil & Detected & 1 & \multirow{2}{*}{ Enterobacteriaceae (Nil/swab) } & \\
\hline Nil & Detected & 2 & & \\
\hline $2.5 \times 10^{2 \mathrm{~b}}$ & $9.3 \times 10^{4 a}$ & 1 & \multirow{2}{*}{ Total plate count (1000cfu/swab) } & \multirow{10}{*}{ Ishida $^{(\mathrm{D})}$} \\
\hline $3.3 \times 10^{2 \mathbf{b}}$ & $8.9 \times 10^{5 \mathrm{a}}$ & 2 & & \\
\hline Nil & $2,1 \times 10^{3 \mathrm{a}}$ & 1 & \multirow{2}{*}{ Mold \& yeast (Nil/swab) } & \\
\hline Nil & $1.2 \times 10^{3 \mathrm{a}}$ & 2 & & \\
\hline Nil & Detected & 1 & \multirow{2}{*}{ Staphylococcus aureus (Nil/swab) } & \\
\hline Nil & Detected & 2 & & \\
\hline Nil & Detected & 1 & \multirow{2}{*}{ Bacillus cereus (Nil/swab) } & \\
\hline Nil & Nil & 2 & & \\
\hline Nil & Detected & 1 & \multirow{2}{*}{ Enterobacteriaceae (Nil/swab) } & \\
\hline Nil & Detected & 2 & & \\
\hline
\end{tabular}

*The limits are according to American public health association. cfu/swab = colony forming unite/swab. $1000 \mathrm{cfu} / \mathrm{swab}=1 \mathrm{cfu} / 100 \mathrm{Cm}^{2}$

*Values followed by different letter in row are significantly different at $\mathrm{p}<0.05 . * \mathrm{~A}, \mathrm{~B}, \mathrm{C}, \mathrm{D}$ comparison of means by location. 
TABLE 5. Microbiological and physical analysis of water sample used in the manufacturing process.

\begin{tabular}{|c|c|c|}
\hline Results & Limits & Parameters \\
\hline & & Microbiological tests \\
\hline 18 & $\square 50$ & Total plate count at $37^{\circ} \mathrm{C}(\mathrm{cfu} / \mathrm{ml})$ \\
\hline 25 & 050 & Total plate count at $22^{\circ} \mathrm{C}(\mathrm{cfu} / \mathrm{ml})$ \\
\hline Nil & Nil & Coliform group $(\mathrm{cfu} / 100 \mathrm{ml})$ \\
\hline Nil & Nil & E. Coli $(\mathrm{cfu} / 100 \mathrm{ml})$ \\
\hline \multirow[t]{2}{*}{ Nil } & Nil & Enterococcus (cfu/100ml) \\
\hline & & Physical properties: \\
\hline Clear & Clear & Color \\
\hline Not found & Not found & Smell \\
\hline Acceptable & Acceptable & Taste \\
\hline Not found & 2(N.T.U) & Turbidity \\
\hline 353 & - & Electric conductivity \\
\hline 7.0 & $6.6-8.6$ & pH value \\
\hline
\end{tabular}

ND: Not detected. (N.T.U) Nephelometric turbidity unit. The limits are according Egyptian standard of drinking water \& ice standard test method part -1 (drinking water) (ES: 190-1 / 2007). Methos according to (ISO9308-1/2000).

TABLE 6. Microbiological analysis of swabs taken from workers for two processing lines (manual sorting) and two packaging lines (seasoning) before and after washing and disinfecting the hands.

\begin{tabular}{|c|c|c|c|c|c|c|c|}
\hline $\begin{array}{c}\text { Enterobacteriaceae } \\
\text { Nil / swab }\end{array}$ & $\begin{array}{c}\text { Staphylococcus } \\
\text { aureus } \\
\text { Nil / swab }\end{array}$ & $\begin{array}{c}\text { Bacillus } \\
\text { cereus } \\
\text { Nil / swab }\end{array}$ & $\begin{array}{c}\text { Mold } \\
\& \\
\text { yeast } \\
\text { Nil / swab }\end{array}$ & $\begin{array}{c}\text { Total } \\
\text { plate } \\
\text { count } \\
\text { 1000cfu/ } \\
\text { swab* }\end{array}$ & $\begin{array}{c}\text { Tests } \\
\& \\
\text { Limits }\end{array}$ & Worker & Location \\
\hline Nil & Detected & Detected & $50 \times 10^{2}$ & $3 \times 10$ & Before & \multirow[b]{2}{*}{1} & \\
\hline Nil & Nil & Nil & Nil & $9 \times 10$ & After & & $=$ \\
\hline Detected & Detected & Nil & $64 \times 10$ & $9.6 \times 10^{3}$ & Before & \multirow[b]{2}{*}{2} & ટి \\
\hline Nil & Nil & Nil & Nil & $4 \times 10$ & After & & 总. \\
\hline Nil & Detected & Nil & $72 \times 10$ & $2.8 \times 10^{3}$ & Before & \multirow[b]{2}{*}{3} & 葛 \\
\hline Nil & Nil & Nil & Nil & $5 \times 10$ & After & & $\widehat{\bar{E}}$ \\
\hline Detected & Nil & Detected & $50 \times 10$ & $9.1 \times 10^{3}$ & Before & \multirow{2}{*}{4} & 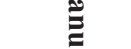 \\
\hline Nil & Nil & Nil & Nil & $4 \times 10$ & After & & $\triangleq$ \\
\hline Nil & Detected & Detected & $87 \times 10$ & $4.2 \times 10^{4}$ & Before & \multirow[b]{2}{*}{5} & $\mathscr{E}$ \\
\hline Nil & Nil & Nil & Nil & $3 \times 10$ & After & & : \\
\hline Detected & Detected & Nil & $90 \times 10$ & $6.2 \times 10^{4}$ & Before & \multirow[b]{2}{*}{6} & 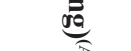 \\
\hline Nil & Nil & Nil & Nil & $7 \times 10$ & After & & $\hat{E}$ \\
\hline Detected & Detected & Detected & $4 \times 10^{2}$ & $2.9 \times 10^{3}$ & $\begin{array}{l}\text { Before } \\
\text { After }\end{array}$ & \multirow[t]{2}{*}{1} & \\
\hline Nil & Nil & Nil & Nil & $7 \times 10$ & $\begin{array}{l}\text { After } \\
\text { Before }\end{array}$ & & $\nabla$ \\
\hline Detected & Detected & Detected & $2.5 \times 10^{2}$ & $4.8 \times 10^{3}$ & & \multirow{2}{*}{2} & है \\
\hline Nil & Nil & Nil & Nil & $1.2 \times 10^{2}$ & After & & (1) \\
\hline Detected & Detected & Detected & $8 \times 10$ & $8.5 \times 10^{3}$ & Before & \multirow[b]{2}{*}{3} & 䈍. \\
\hline Nil & Nil & Nil & Nil & $2 \times 10^{2}$ & After & & \\
\hline Detected & Nil & Detected & $22 \times 10$ & $1.7 \times 10^{4}$ & Before & \multirow[b]{2}{*}{4} & $\sqrt[5]{8}$ \\
\hline Nil & Nil & Nil & Nil & $3 \times 10^{2}$ & After & & 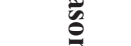 \\
\hline Nil & Detected & Nil & $99 \times 10$ & $3.2 \times 10^{4}$ & Before & \multirow[b]{2}{*}{5} & E. \\
\hline Nil & Nil & Detected & $5 \times 10$ & $2.9 \times 10^{3}$ & After & & $\underbrace{\sqrt[0]{0}}_{=}$ \\
\hline Detected & Detected & Detected & $3.2 \times 10^{2}$ & $1.4 \times 10^{2}$ & Before & \multirow[b]{2}{*}{6} & \\
\hline Nil & Nil & Nil & Nil & $6 \times 10$ & After & & \\
\hline
\end{tabular}

The limits are according to American public health association: 1000/swab for total plate count Nil/swab for Mold \& yeast Bacillus cereus, Staphylococcus aureus and Enterobacteriaceae.

${ }^{*} \mathrm{cfu} / \mathrm{swab}=$ colony forming unite $/ \mathrm{swab} .1000 \mathrm{cfu} / \mathrm{swab}=1 \mathrm{cfu} / 100 \mathrm{Cm}^{2}$.

* Values followed by different letter in column are significantly different at $p<0.05$.

* $A, B$ comparison of means by location. 


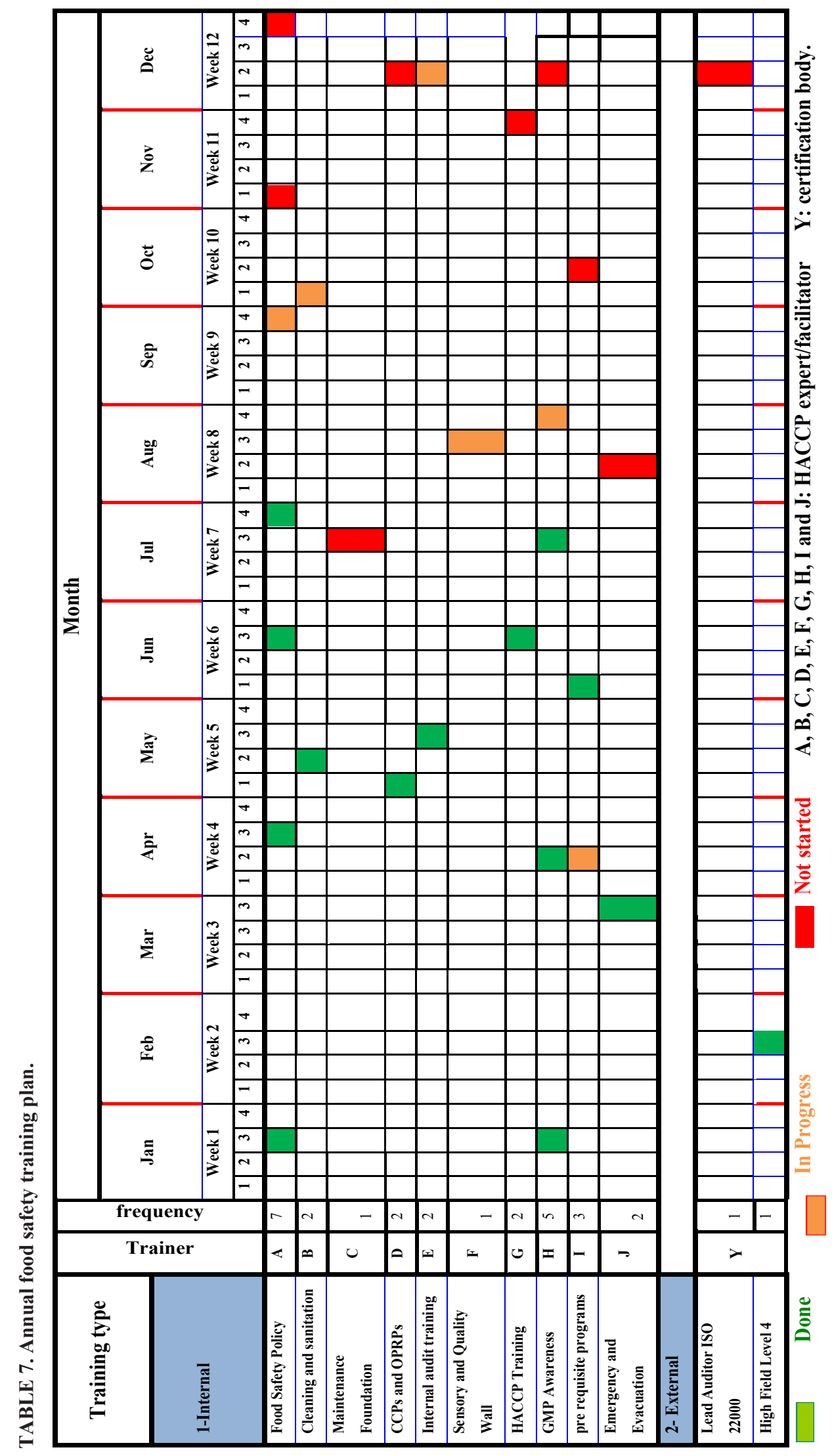

Egypt. J. Food. 48, No.1 (2020) 


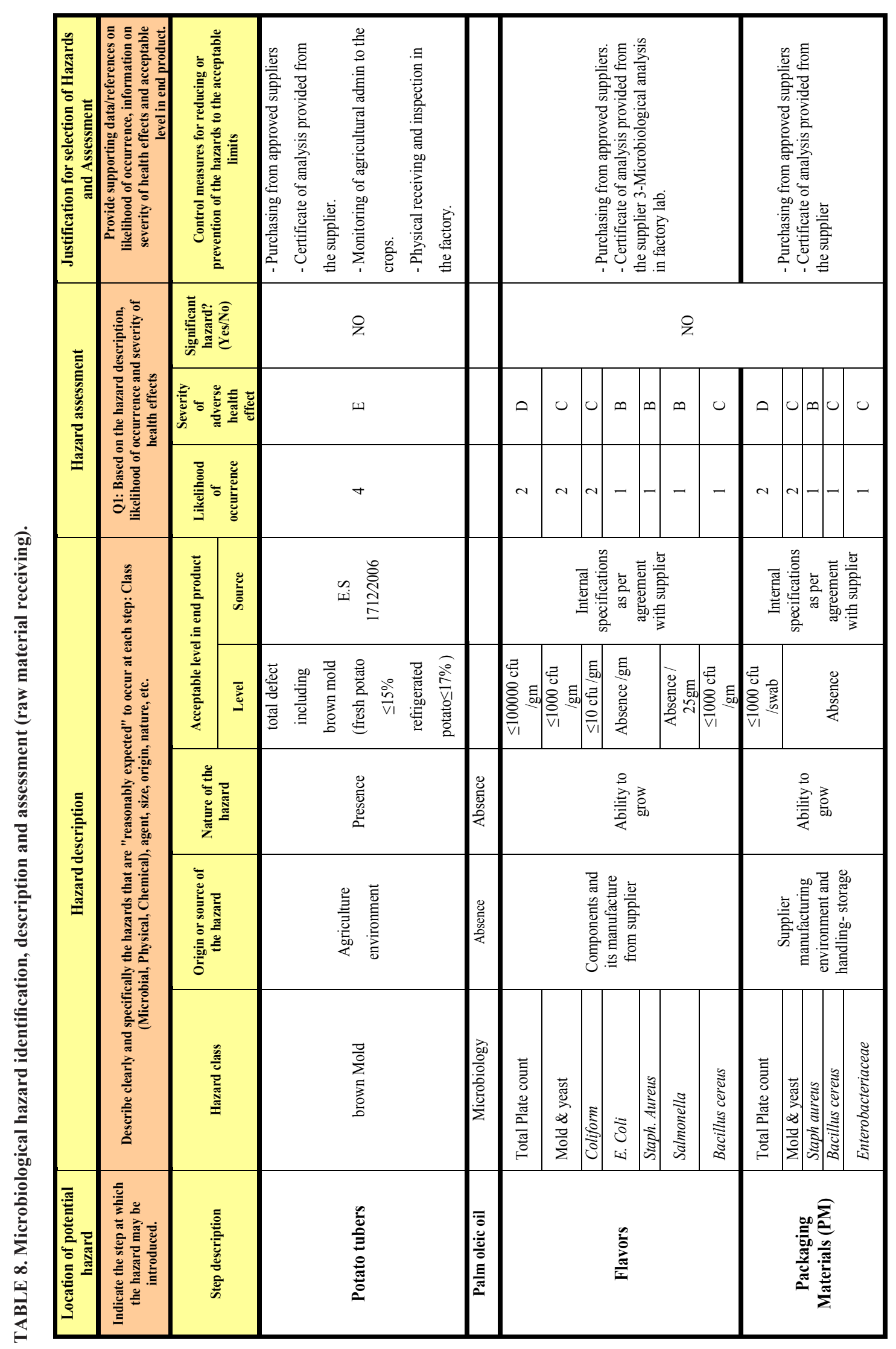

Egypt. J. Food. 48, No.1 (2020) 


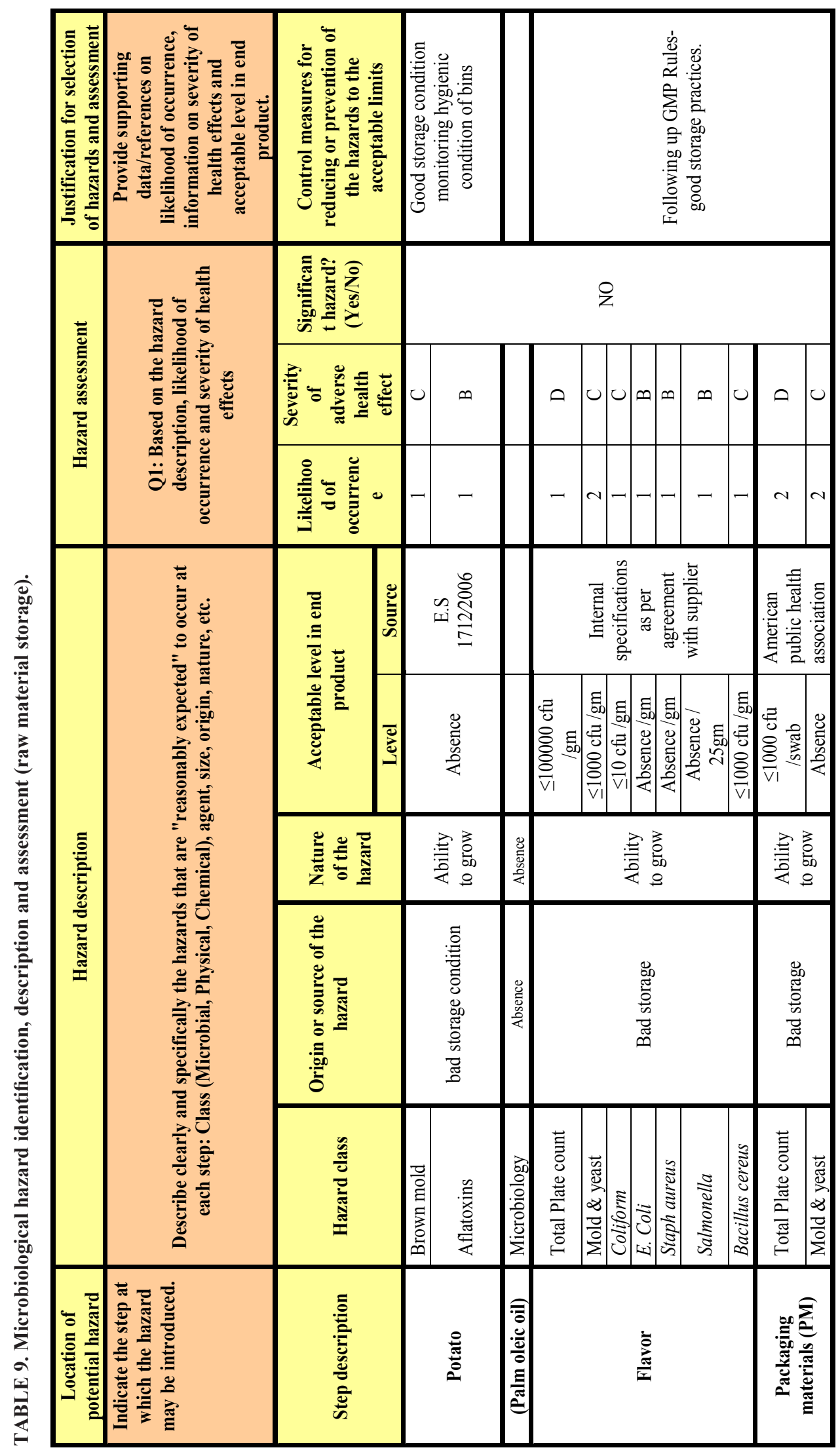

Egypt. J. Food. 48, No.1 (2020) 


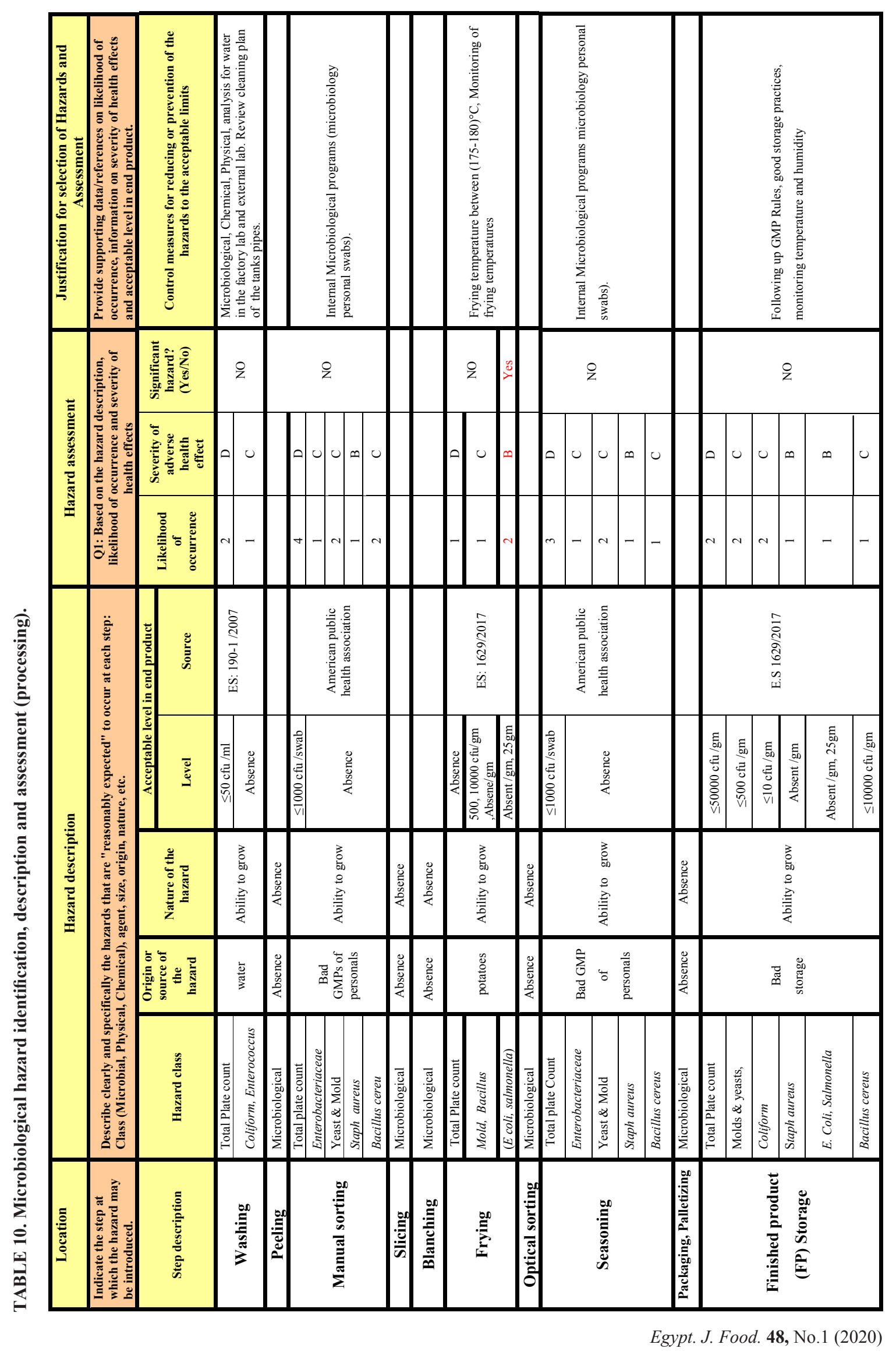




\section{Conclusion}

The HACCP system has proven effectivess in eliminating or minimizing food safety hazards to the acceptable level, provided that PRP programs are implemented through the Food Safety management system ISO 22000 as the HACCP program alone is not sufficient to control all food safety hazards, implementation of FSMS ISO 22000 saves the business money in the long run, where it

- Reduce and support the traditional inspection and quality procedure

- reduce fines and legal costs resulting from prosecution.

- make good reputation of company, increasing sales and profit. So we recommend to apply FSMS ISO 22000 for food establishments to ensure safe product.

\section{References}

Abd-Elgawad, M. M. and Youssef, M. (2008) Programs of research development in Egypt. First International Workshop on Ecology and Management of Plant-parasitic Nematode Communities in South-Mediterranean Ecosystems, 17-19 March, Sousse, Tunisia.

Bardic, A. (2001) HACCP Ready. Dairy Field, 184 (2), 6.

CAC/RCP-4 (2003) Recommended international Code of practice general principles of food hygiene. In Codex Alimentarius commission Food Hygiene Basic Texts, $4^{\text {th }}$ edition. Food and Agriculture Organizations of the United Nations, World Health Organization, Rome.

Codex (2009) Joint FAO/WHO Food Standards Programme, Codex Alimentarius Commission, Committee on Food Hygiene. Hazard analysis and critical control point (HACCP) system and guidelines for its application. Food Hygiene Basic Texts, fourth edition. Joint FAO/WHO Food Standards Programme, Food and Agriculture Organizations of the United Nations, World Health Organization, Rome.

E.S. 1629 (2017) Egyptian organization for standardization and quality for Fried potato (28/8/2017).

Easdani, M.; Khaliduzzaman and Bhuiyan, M. H. R. (2012) The Design of HACCP Plan for Potato Chips Plant in Bangladesh. J. Environ. Sci. \& Natural Resources, 5 (2), 329 - 338.

Egypt. J. Food. 48, No.1 (2020)
ES: 190-1 (2007) Drinking water and ice standard test method part -1 .

Forsythe, S. J. and Hayes, P. R. (1998). Food Hygiene, Microbiology and HACCP and product quality. $3^{\text {rd }}$ ed. Aspen Publishers, Inc. Gaithersburg, Maryland.

FSSC 22000 (2019) Food safety system certification 22000 Gudance decument: ISO 22000 international Version: 5.

Geiger, A. (2011) Analysis of Raw Potato Sorting Technology on A Potato Chips Line. M.Sc. OF Agribusiness Thesis Depart. of Agric. Econom., College of Agriculture, Kansas State Univ., Manhattan, Kansas.

Hirano, H. (1995) Five pillars of the visual workplace, 398, Productivity Press, New York.

ISO 16649-2 (2001) International Standardization Organization. ISO 16649-2. Horizontal method for enumeration of B - glucronidase - positive $E$. coli colony count technique at $44^{\circ} \mathrm{C}$ - part 2 first edition.

ISO 21528-2 (2004) International Standardization organization ISO21528-2. Horizontal method for enumeration of detection enumeration of Enterobacteriaceae - part 2 third edition.

ISO 2157-2 (2008) International Standardization organization. ISO 2157-2. Horizontal method for enumeration of Molds yeast \& colony count technique in products with water activity $-<0.95$ part 2.

ISO 22000 (2018) International Standardization organization ISO 22000. Food safety management systems-Requirements for any organization in the food chain - second edition.

ISO 48332 (2006) International standardization ISO 4833. Horizontal method for enumeration of coliforms- colony count technique.

ISO 6579 (2002) International Standardization organization ISO 6579. Horizontal method for detection of salomonella spp- fourth edition.

ISO 6887-1 (1999) International Standardization organization ISO 6887-1. General rules preparation of test sample, initial suspension \& decimal dilutions for microbiological examination- part 1

ISO 6888-1 (2003) International Standardization Organization ISO 6888-1. Horizontal method for enumeration of Staphylococcus aureus-part1.

ISO 7932 (2004) International Standardization Organization. ISO 7932 Horizontal method for 
enumeration of presumptive bacillus cereuscolony count techniques at $30^{\circ} \mathrm{C}$.

ISO 9308-1 (2000) International Standardization Organization.ISO 9308. Water quality detection \&enumeration of E. coli \& coliform bacteria membrane filtration- part1.

ISO-TS22002-1 (2009) International Standardization Organization ISO-TS22002-1. Prerequisite programmes on food safety Part 1- Food manufacturing.

Khatab, Heba, A. (2014) Controlling of microbial hazard during the processing of mango pulp and juice through food safety management system (ISO 22000). MSc. Thesis, Food science and technology Depart., Fac. of Agric. Tanta Univ.
Microbiology of feed and animal feeding stuffs preparation of test samples Initial suspension and decimal dilutions for microbiological examination -part1.

Noble, R.; Elphinstone, J.G.; Sansford, C.E.; Budge, G. E. and Henry, C. M. (2009) Management of plant health risks associated with processing of plantbased wastes: A review, Bioresource Technology, $100,3431-3446$.

SCV (2006) Requirements for a HACCP based Food Safety, Option A: Management System Certification. National Board of Experts-HACCP. The Netherlands.

\section{التحكم في المخاطر الميكروبيولوجية لتصنيع رقائق البطاطس من خلال نظام إدارة سلامة

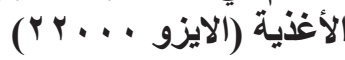

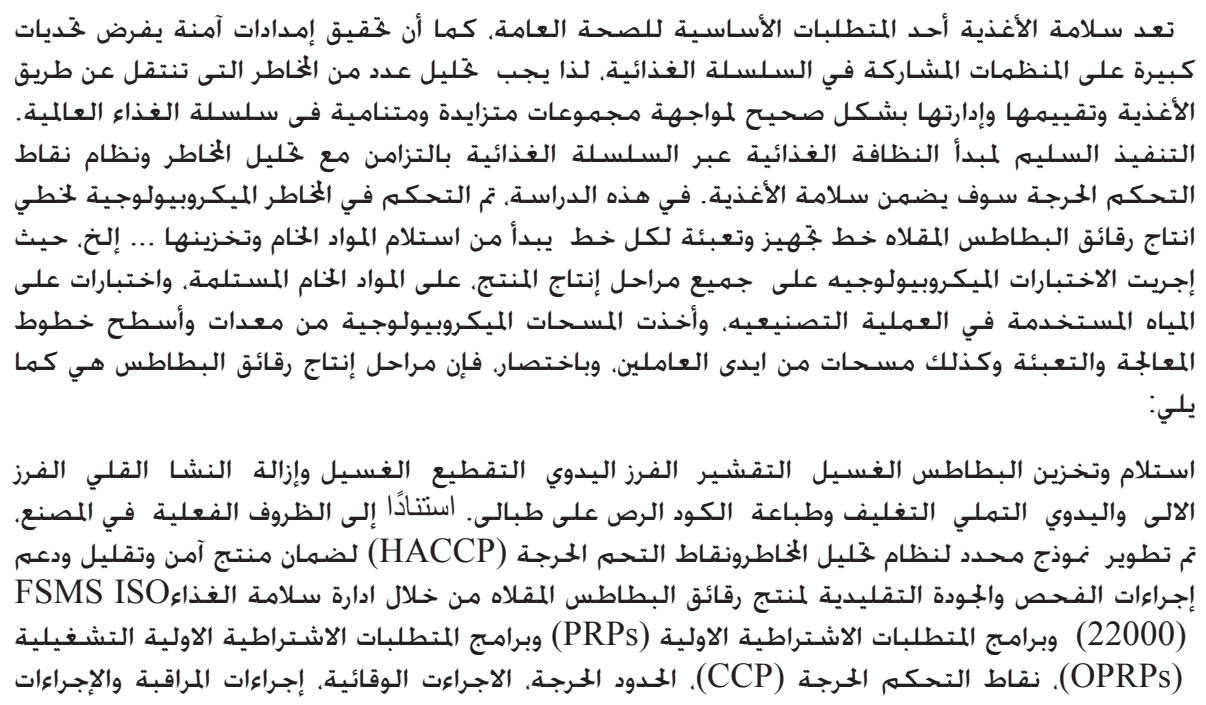

